\title{
Nutritive Value of Botanical Fraction in Maize By- Products from Various Varieties
}

\author{
Endang Sutedi ${ }^{1, *}$, Budi Utomo ${ }^{2}$, and Heri Kurnianto ${ }^{2}$ \\ ${ }^{1}$ Indonesian Research Institute for Animal Production, Bogor. PO Box 221. Indonesia \\ ${ }^{2}$ Assessment Institute for Agriculture Technology, Central Java. Indonesia \\ "Corresponding author.Email: endangsutedi@yahoo.co.id
}

\begin{abstract}
This study was conducted to evaluate botanical fraction from three varieties of maize by-products. Maize varieties evaluated were Bisi 816, Pioneer 12 and Bima2 obtained from different locations. The plants were harvested at the grain maturity stage. The stover was partitioned based on its botanical fraction into cobs and stover components. The cobs were separated into the grain, ear husk, and cob, while stover was separated into leaf and stem. Each fraction was cut and dried then ground and ready to be evaluated. The evaluation was chemical analysis (crude protein, neutral detergent fiber, acid detergent fiber, lignin, gross energy, metabolizable energy) and in vitro dry matter and organic matter digestibility (IVDMD and IVOMD). The study was conducted in randomized complete design in factorial $3 \times 4$ (three varieties and 4 botanical fractions). The study revealed that leaf fraction had the highest content of crude protein (CP) in all varieties with ranges 6.1-11.58\%. Though ear husk has lower CP content than leaf, it has high IVDMD and IVOMD in all varieties. The highest in vitro digestibility among botanical fraction were in the leaf and ear husk. From this study can be concluded that the good nutritive quality of botanical fraction in all varieties as ruminants feed were in leaf and ear husk.
\end{abstract}

Keywords: Nutritive values, Botanical fraction, Maize, Varieties.

\section{INTRODUCTION}

Corn is one of food crops targeted by Indonesian government to be domestically self-sufficient as food and feed sources and can be exported. Grain production will be followed by increased corn by-products which can be utilized for ruminant feeds. To achieve this target, high production corn varieties was introduced and developed in Indonesia. Those varieties included Bisi816, Pioneer12 and Bima2. Each of these variety has superiority from corn production and survivability from disease attack and environmental condition.

By-products from maize crop (such as stover, cob and ear husk) are usually used as ruminants feed. Corn variety was reported affect its by-products quality. Umiyasih and Anggraeni [1] and Liang et al [2] reported that nutritive value stover from a various varieties of corn was varied. This nutritive value was affected by the composition of its botanical fraction. Corn stover which contained high proportion of leaf, had a higher nutritive value than stover [3]. Limited information available in Indonesia on the effect of varieties on the nutritive value of botanical fraction of corn by products. The objective of this study was to evaluate the nutritive value botanical fraction of corn by-products.

\section{MATERIALS AND METHODS}

\subsection{Feed materials and preparation}

The study was conducted using three corn varieties consisted of 2 hybrid verities breed imported from overseas (Bisi816 and Pioneer12) and 1 hybrid variety (Bima2) bred in Indonesia (bred by Indonesian Cereals Research Institute, Maros, South Sulawesi). Bima 2 is dual purpose variety selected for high grain production and stay green stover used for feed source. The byproduct from harvested corn of each variety was collected from different field farm. Pioneer variety was collected from a farm in. Cicurug, Sukabumi district and 
Bisi variety collected from Wirasari, Grobogan district. Whereas Bima2 variety was collected from the IRIAP field station in Bogor. The corn was harvested at mature grain. After the ear was harvested, the stover was collected by cut the plant and stem was left at $10 \mathrm{~cm}$ above ground. The stover was separated between stem and leaves. While the ear was separated into grain, cob and ear husk. Those botanical fractions of stover (stem and leaf) and ear (husk and cob), were hopped into $5 \mathrm{~cm}$ in length, and dried in oven at $60 \mathrm{oC}$ for 48 hours. After dry the samples were then ground and ready to be analysed. To determine the nutritive value of the samples, the ground samples was analysed for its chemical composition and in vitro digestibility.

\subsection{Chemical analysis and invitro digestibility}

Gross Energy (GE), crude protein (CP) content were analyzed according to AOAC [4] Neutral detergent fiber (NDF) and acid detergent fiber (ADF), content were analysed according to Van Soest [5].The in vitro digestibility was carried out using method of Menke and Steingass [6] metabolizable energy (ME) was calculated from MAFF (1984) [7] equation. To measure the in vitro digestibility the residue from the incubation was reflux with NDF solution for 1 hour [8]. The rumen fluid used for medium was collected from rumen of sheep fed on fresh elephant grass and concentrate.

\subsection{Design experiment and data analysis}

The study was conducted using randomized complete design in factorial $3 \times 4$ (three varieties and four botanical fractions) with four replication of each treatment. Data obtained were analysed using SAS 9 vs $1[9]$.

\section{RESULTS AND DISCUSSION}

The statistical analysis of the data shows that there were significant interaction between corn varieties and botanical fraction on the nutritive quality of the samples analyzed. Compare to other botanical fraction, leaf had the highest protein content in all varieties. Lynch and Doyle [3] and Methu et al [10] also reported that leaf had highest protein content than other fraction. However $\mathrm{CP}$ content in leaf between varieties was different, this differences could be caused by different varieties [11]. The CP content between varieties in each botanical fraction was varied. In Pioneer the lowest $\mathrm{CP}$ content was in ear husk, while Bisi and Bima varieties the $\mathrm{CP}$ content in ear husk, stem and cob were not significantly different.

All varieties highest GE energy content was in the cob followed by ear husk. While the lowest was in the leaf. Similar to GE content the NDF content was also highest in the cob followed by ear husk. The highest of NDF content of this fraction might be the reason of the highest GE content of this fraction. NDF is the component of plant cell wall, which needed to support the plant for standing. Therefore the highest NDF content was in the stem [12]. Beside that by the time the plant reach maturity stage, the cell wall component deposited in the stem than in the leaf, therefore leaf usually had low content of cell wall [3]. In all varieties leaf had the lowest NDF content. The ADF content between cob, stem and ear husk were similar in all varieties while the leaf had the lowest ADF content. Dry matter and organic matter in vitro digestibility (IVDMD and IVOMD) were highest in leaf and followed by ear husk. The highest digestibility in the leaf caused by the lowest cell wall content in the leaf. Beside that the leaf also had highest protein content. Therefore leaf had highest digestibility. Lynch and Doyle [3] reported that protein content in the leaf was the degradable protein in the rumen in which the ammonia available from this degradable protein is needed for Synthesize protein microbial which in turn it will increase feed digestibility. Piriera et al [13] also reported that leaf had highest degradability than other botanical fraction of corn plant. Meanwhile earhusk also had higher in vitro digestibility compare to stem and cob. Eventhough earhusk had high content of NDF but this NDF had higher digestibility as reported by [14]. Moreover earhusk also had lower lignin content than other fraction. The higher digestibility resulted in higher ME content of leaf and earhusk. The higher digestibility in the leaf and earhusk influence its palatability. Methu et al [10] reported that when dairy cattle given free choice feeding of botanical fraction of corn stover, the cattle choose to consume the leaf and earhusk. Considering the protein content and digestibility of the leaf, therefore the quality of biomass from corn farming is affected the by the proportion of the leaf. Therefore, to be used as ruminants feeding the selection of maize variety also recommended selecting the plant with high leaf proportion beside high grain production. 
Table1.Chemical composition and in vitro digestibility of botanical fraction from the by-product of maize plant.

\begin{tabular}{|c|c|c|c|c|c|}
\hline \multirow{2}{*}{ Chemical composition } & \multirow[b]{2}{*}{ Variety } & \multicolumn{4}{|c|}{ Botanical Fraction } \\
\hline & & Ear husk & Stem & Leaf & $\mathrm{Cob}$ \\
\hline \multirow[t]{3}{*}{ Crude protein (\%) } & Bisi816 & $1.54 \mathrm{gf}$ & $1.89 f$ & $6.10 \mathrm{c}$ & $1.56 \mathrm{gf}$ \\
\hline & Pioneer12 & $1.15 \mathrm{~g}$ & $3.22 \mathrm{e}$ & $11.58 a$ & 3.60de \\
\hline & Bima2 & $3.79 d$ & $3.68 d$ & $7.10 \mathrm{~b}$ & $3.78 d$ \\
\hline \multirow[t]{3}{*}{ Gross Energy (kkal/kg) } & Bisi816 & $3823 d$ & $3857 d$ & $3815 \mathrm{de}$ & $3998 b$ \\
\hline & Pioneer12 & $3861 d$ & 3767 ef & $3736 g f$ & $4054 a$ \\
\hline & Bima2 & $3847 d$ & $3715 \mathrm{~g}$ & $3624 \mathrm{~h}$ & $4054 a$ \\
\hline \multirow[t]{3}{*}{$\operatorname{NDF}(\%)$} & Bisi816 & $80.21 b$ & $75.7 \mathrm{c}$ & $64.9 \mathrm{~g}$ & $82.3 a$ \\
\hline & Pioneer12 & $80.7 b$ & $69.9 f$ & $60.6 \mathrm{i}$ & $80.5 b$ \\
\hline & Bima2 & $74.4 d$ & $72.6 e$ & $63.3 \mathrm{~h}$ & 73.5de \\
\hline \multirow[t]{3}{*}{ ADF (\%) } & Bisi816 & 42.0de & 43.3bcd & $35.98 \mathrm{~g}$ & $43.8 b c$ \\
\hline & Pioneer12 & $44.3 b$ & $43.4 \mathrm{bcd}$ & $34.8 \mathrm{~g}$ & $42.5 \mathrm{cde}$ \\
\hline & Bima2 & 41.5ef & $50.5 a$ & $42.5 \mathrm{cde}$ & $40.4 f$ \\
\hline \multirow[t]{3}{*}{ Lignin (\%) } & Bisi816 & $3.11 \mathrm{~g}$ & $4.5 \mathrm{e}$ & $3.05 \mathrm{gh}$ & $6.01 \mathrm{c}$ \\
\hline & Pioneer12 & $2.78 \mathrm{~h}$ & $4.1 f$ & $3.36 \mathrm{~g}$ & $6.59 b$ \\
\hline & Bima2 & $5.10 d$ & 7.3a & $4.68 \mathrm{e}$ & $5.2 d$ \\
\hline \multirow{3}{*}{$\begin{array}{l}\text { IVDMD (\%) } \\
\text { beres }\end{array}$} & Bisi816 & $62.5 \mathrm{bc}$ & $60.4 c$ & $68.9 a$ & $50.4 d$ \\
\hline & Pioneer12 & $63.1 \mathrm{bc}$ & $61.0 \mathrm{c}$ & $62.71 \mathrm{bc}$ & $51.8 d$ \\
\hline & Bima2 & $64.5 \mathrm{~b}$ & $48.8 d$ & $63.4 \mathrm{bc}$ & $60.1 \mathrm{c}$ \\
\hline \multirow{3}{*}{$\begin{array}{l}\text { IVOMD (\%) } \\
\text { beres }\end{array}$} & Bisi816 & $62.0 \mathrm{bc}$ & $58.3 d$ & $66.9 a$ & $49.9 e$ \\
\hline & Pioneer12 & $62.2 \mathrm{bc}$ & $58.6 d$ & $61.23 \mathrm{bcd}$ & $51.7 e$ \\
\hline & Bima2 & $64.2 \mathrm{ab}$ & $44.0 f$ & $62.0 a$ & $60.7 \mathrm{~cd}$ \\
\hline \multirow[t]{3}{*}{ ME (kal/kg) } & Bisi816 & $2002 a b$ & $1821 \mathrm{de}$ & 2068a & $1616 \mathrm{~g}$ \\
\hline & Pioneer12 & $1947 b c$ & 1789 ef & $1853 \mathrm{cde}$ & 1699gf \\
\hline & Bima2 & $1919 b c$ & $1322 \mathrm{~h}$ & $1821 \mathrm{de}$ & $1943 b c$ \\
\hline
\end{tabular}

Different letter in row and column indicated significantly different $(\mathrm{P}<0.05)$.

\section{CONCLUSION}

Good nutritive quality of botanical fraction in all varieties as ruminants feed was in leaf and earhusk based on in vitro digestibility and crude protein content of the fractions.

\section{REFERENCES}

[1] U. Umiyasih and Y.N Anggraeni. 2005. Prosiding Seminar Nasional Teknologi Peternakan dan Veteriner (in Bahasa) 2005. Bogor 12-13 September 2005. Pp. 125-130

[2] Liang Ming-Yuan,Wang Gui-Yan, Liang Wei-Li, Shi Peng-Fei, Dang Jing, Sui Peng, Hu Chunsheng. 2015. Journal of Integrative Agriculture 14, $1581-1587$
[3] J.P. Lynch, E.M. Doyle. 2014. Irish Journal of agricultural and Food Research 53: 205-211.

[4] AOAC. 1990. Association of Official Analytical Chemist, Official Method of Analysis. 12th Edition. AOAC, Washington. US

[5] P.J. Van Soest, J.B. robertson and B.A. Lewis. 1991. J. Dairy Sci. 74: 3583-3593.

[6] K.H. Menke and H. Steingass. 1988. Anim.Res. Dev. 28: 7-55.

[7] MAFF. 1984. Energy Allowances and Feeding System For Ruminants. Ministry of Agriculture, Fisheries and Food. HMSO, London

[8] M. Blummel, H. Steingass and K. Becker. 1997. Br. J. Nutr. 77: 911-921. 
[9] SAS. 2004. SAS/STAT User's Guide (Release 9.1) SAS Inst, Inc. Carry, NC, USA

[10] Jn. Methu, E. Owen, Al. Abate, Jc. Tanner. 2001. By Dairy Cattle. 71:87-96.

[11] JZ. Barbosa, CF. Ferreira, N. Zendonadi. 2016.In Response To Cultivar Development. 40:665-675.

[12] T.L. Slewinski, 2012. Journal of Experimental Botany 63: 4647-4670

[13] Pereira José Luiz de Andrade Rezende, Renzo Garcia Von Pinho, Alano Xavier Souza Filho, Marcos Neves Pereira, Álvaro de Oliveira Santos, Iran Dias Borges. 2012. R. Bras. Zootec. 41 (5): 1110-1117

[14] Ming-Yuan L, Gui-Yan W, Wei-Li L, Peng-Fei Shi, Jing D, Peng Sui. 2015. Yield and Quality Of Maize Stover: Variation Among Cultivars And Effects Of N Fertilization. 3119. 